\title{
Relationship Between Selected Macroeconomic Variables and the Financial Performance of Investment Banks in Kenya
}

\author{
Mungiria James Baariu ${ }^{1} \&$ Njuguna Peter ${ }^{1}$ \\ ${ }^{1}$ KCA University, Kenya \\ Correspondence: Mungiria James Baariu, KCA University, Kenya.
}

Received: July 28, 2021

Accepted: October 27, 2021

Online Published: October 28, 2021

doi:10.5539/ijef.v13n11p102

URL: https://doi.org/10.5539/ijef.v13n11p102

\begin{abstract}
Currently, investment banks in Kenya are facing a lot of challenges due to persistence losses. However, the available studies are inadequate to aid investment banks in overcoming these challenges in Kenya due to mixed findings, resulting in rising uncertainty on equity investments' performance, leading to massive losses among investment banks. This study, therefore, sought to model the relationship between inflation, GDP, interest rates, exchange rates, and financial performance of investment banks. Arbitrage pricing theory, Modern portfolio theory as well as classical economic theory (flow-oriented model) was used. A causal research design was adopted. The study found that inflation has negative significant influence on financial performance of equity investments among investment banks in Kenya. Also, GDP has positive and significant influence on financial performance of equity investments among investment banks in Kenya. Interest rate was also found to have negative and significant influence on financial performance of equity investments among investment banks in Kenya. In addition, exchange rate has negative significant influence on financial performance of equity investments among investment banks in Kenya. The study therefore recommends any investor including financial investors to methodically analyze inflation trends and understand how it affects the company's financial performance. Investors must also be in a position to predict the future concerning inflation changes.
\end{abstract}

Keywords: investment bank, equity investment, macroeconomic variables, Return on Asset

\section{Introduction}

Over the years, investment banks have undergone many transformations, beginning just as partnership companies primarily offered underwriting security issuance to more advanced services such as proprietary trading, securities research, and investment management. In the United States, investment banking dates back to the $18^{\text {th }}$ and $19^{\text {th }}$ centuries but gained popularity after enacting the Glass Steagall act in 1933 during the great depression that saw over $40 \%$ of banks either shut down or forced to merge. This law aimed at solving the problem created by the banking industry by erecting a wall to disconnect investment banking from commercial banking. During this period, the majority believed that the banking industry was too greedy, therefore invested in very risky securities using depositor's funds. However, after implementing this law, there was great concern that this legislation created an unhealthy environment in the financial sector hence disadvantaged local banks compared to foreign banks that offered investment and commercial banking. Therefore, this concern triggered the repealing of the Glass Steagall Act by passing the Gramm Leach Bliley Act 1999. The repealing of the act led to many other investment banks' birth, and today the world's largest investment banks come from the United States. These banks have been leaders worldwide for some time, such as Bank of America, Deutsche Bank, Credit Suisse, Barclays, UBS, and JPMorgan Chase.

The United Kingdom, which recently discontinued its European Union membership, is the second robust country in the investment banking industry. Initially, the UK investment banks were more focused on capital market intermediation until investment banks from the United States entered the European and UK markets and forced them to introduce other investment banking services. Today, London is one of the leading investment banking hubs in Europe and globally dominated by top investment banks, including Credit Suisse, Morgan Stanley, JPMorgan, Citibank, Merrill Lynch, UBS, and Bank of America, among others

In Africa, investment banking has flourished in the last two decades. These include Lagos based investment banks Chapel Hill, Afrinvest, Vetiva, and Ecobank Capital, which started in 2010 and thriving well on African markets with over 700 branches and representative offices in 35 countries, mostly in Africa. South African Investment 
banks' capabilities are said to be on par with those in Western countries. For instance, Absa Capital has implemented multi-billion projects like led debut 144a/RegS bonds for Eskom and AngloGold Ashantiqw's 10-year and 30-year notes, summing up to $\$ 1 \mathrm{bn}$. In 2010, Rand Merchant bank participated in the financing of Trafigura, a Dutch commodities firm, to purchase BP downstream assets worth $\$ 296 \mathrm{~m}$ in East and Southern Africa. Further, Stanbic IBTC (Nigeria) was picked as underwriting manager $\$ 104 \mathrm{~m}$ and $\$ 306 \mathrm{~m}$ bonds for Ebonyi and Bayelsa states respectively and joined lead manager on a seven-year note valued $\$ 352 \mathrm{~m}$ for Lagos state (African Business Magazine, 2018).

In Kenya, the investment banking industry has been growing annually, signifying its importance in the Kenyan economy. Today Kenya is boosting 16 investment banks licensed CMA (2020) since 2002 when African Alliance (K) Ltd was licensed (CMA, 2002). Investment banks have also increased their product portfolio to serve diverse market needs and improve their earnings. Offering an expanded product portfolio has been made possible by technological advancements in the banking sector (Ongore, 2013). According to Kurt (2019), as investment banks expand in size, product portfolio, and earnings, investors demand higher returns. The investment banks have not met since they have been making losses or very insignificant profits (Anyanzwa, 2019). According to Audited Financial Results (NSE, 2020), Genghis Capital Limited recorded a loss after tax of Kshs109.9 million. Faida Investment Bank Limited reported a loss of Kshs 49.7 million, ABC Capital recorded losses of Ksh 37.68 million. Equity Investment Bank recorded a loss of Ksh 18.82 million, while NCBA recorded a loss after tax of Ksh 3.7 million. On the other hand, the Audited report 2019 reviewed that Genghis Capital Limited registered a loss after tax of Kshs 53.7 million (Audited Financial Results NSE, 2020).

Globally, in the year 2019, Investment banks registered a decline in revenue. Dealogic Quarterly Rankings (2020) reported that investment banks registered a decrease in revenue by 5 percent from $\$ 79.8 \mathrm{bn}$ in 2018 to $\$ 76 \mathrm{bn}$ in 2019. This global decline was associated with a reduction in several regions where Europe registered the highest drop of revenue by $15 \%$, followed closely by Japan which recorded a $13 \%$ decline, followed by Australia which reported an $11 \%$ decrease and North America which reported the lowest drop of 4\% in revenue (Dealogic Quarterly Rankings, 2020).

Investment banks in Kenya are private and government entities registered under the 1989 Capital Markets Authority Act, which empowers, regulates, and overseas investment pursuits CBK, 2008). As of April 2020, (CMA, 2020) reported that the Capital Markets Authority had licensed 16 investment banks listed in Appendix 1. Capital market is a securities market where borrowers raise long-term funds and where investors (lenders) and borrowers (issuer of securities to the public) of capital converge. In 2009, the Capital Markets Regulations were revised to raise the paid-up capital for investment banks from Kshs 30 million to Kshs 250 million as of 1 January 2011 (CMA, 2009). The amendments intended to improve the confidence of investors and the overall stability of the market since a high level of capitalization is correlated with high efficiency and technical capability, thereby enhancing services.

Investment banks in Kenya form an integral component of the financial system that focuses on generating capital for long-term developments for government, companies, and other entities. Investment banks usually assist in the sale of securities, underwrite equity securities and new debts for all types of firms, broker trades for both individuals and firms, and facilitate mergers and acquisitions. Investment banks also guide firms in issuing and placement of securities. They are particularly useful when a firm or individual investor wants to buy and sell shares, bonds, T-bills, and securities (Surbhi, 2017). Investment banks also maintain securities such as equities in corporations, debt securities, money market securities, and mortgage-backed securities. These investment securities provide investment banks with profits from capital gains when sold and the advantage of liquidity (Chen, 2020).

Investment banks own trading where they price shares higher than the purchase price and invest in long-term investments on behalf of investors; therefore, accepting significant risk. Surbhi (2017) observed that investment banks risk losing money if the regulator realizes that they overvalued their shares since they will be forced to sell their shares for less than they paid. Investment banks in Kenya serve diverse clients ranging from private firms, public firms, and the government. Firms such as Standard Investment Bank have been in the investment banking industry for a long time. They have amassed a lot of experience executing private placement, government privatizations, first public offerings, and secondary offerings. Besides, investment banks work with SMEs in Kenya to help them access capital and listing on the market segment of capital markets (Standard Investment Bank, 2020). As argued by (Ruibi, 2016), efficient management of investment banking is a prerequisite towards strengthening its capital bases and asset quality, reduction of operational costs, and pursuing diversification strategies successfully in Kenya. Small investment banks struggle to achieve efficiency; thus, their contribution to the economy is lower than large established counterparts. 


\subsection{Statement of the Problem}

From a broader perspective, it is generally accepted that every investor aims to maximize return on their investment. Bodie (2007) observed that money invested should give back the expected positive returns to the investor since money hidden elsewhere yields nothing to the investor. Streidwolf (2018) noted that investors aim at earning high profits, maximizing their future wealth. NSE (2020) reported that Investment banks in Kenya face increased pressure from investors to give them a decent return. However, on the contrary, the cooperative bank annual financial report 2019 cast a shadow of uncertainty surrounding its investment banking unit (Anyanzwa, 2019). The bank further reported that many commercial banks with investment banking units struggle to sustain them due to persistent losses, therefore agreeing with (Kenya Bankers Association, 2019) assertion that very few investment banks have remained profitable in Kenya. Interestingly, these banks are torn between selling off and shutting down those loss-making business segments since they do not want to send wrong signals on the market since they are considered more capitalized players (Anyazwa, 2019).

According to Audited Financial Results (NSE, 2020), Genghis Capital Limited recorded a loss after tax of Kshs109.9 million; Faida Investment Bank Limited reported a loss of Kshs 49.7 million; ABC Capital recorded Ksh 37.68 million losses. Equity Investment Bank recorded a loss of Ksh 18.82 million, while NCBA recorded a loss after tax of Ksh 3.7 million (Audited Financial Results NSE, 2020). On the other hand, the Audited report NSE 2019 reported that Genghis Capital Limited registered a loss after tax of Kshs 53.7 million (Audited Financial Results NSE, 2020).

Analysts argue that these losses are reflections of flawed strategy and overconfidence. According to (Anyazwa, 2019), commercial banks with investment units capitalized on their vast customer base to build relationships that did not yield much in their investment business units, suggesting that other factors greatly influence equity investment performance. Asaolu and Ogunmuyiwa (2010) reported that macroeconomic variables are barometers for ensuring the economy's performance, while (Nisha, 2015) observed that up-and-coming markets are greatly affected by macroeconomic factors. The Economic survey (2020) reported a slowed down growth where yearly inflation grew from 0.047 in 2018 to 0.052 in December 2019. Similarly, the Real GDP reported in Economic Survey 2020 is approximated to have slimmed down to 0.054 in 2019 , contrasted to 6.3 percent in 2018, denoting a 0.7 percent decrease in growth. Simultaneously, the Kenyan shilling performed well with a 113.0 trade-weighted index in 2019 compared to 115.7 in 2018, implying a 2.3 percent improvement (Economic Survey, 2020). Similarly, a downward adjustment of the Central Bank Rate (CBR), from 0.09 in July 2018 to 0.085 in November 2019, was reported (Economic Survey, 2020).

Several studies have been done on the topic both internationally and locally. Zhang and Dong (2011) carried out research and reviewed that interest rate and GDP are critical macroeconomic variables influencing bank returns. However, this study did not consider investment banks that operate under different regulations, therefore not a representative. Ngeno (2018) surveyed the determinants of investment banks' financial performance in Kenya but only focused on internal variables that affect investment banks. Mutekwa et al. (2017) commissioned a survey regarding factors affecting security trading in Kenya's investment banks. However, this analysis focuses on public awareness, while current studies would examine the effect of macroeconomic factors on the profitability of equity investment. Ruibi (2012) published a report on how Investment Banking is impacting economic growth in Kenya. The finding shows that the total within the investment market influences economic growth. However, the researcher only linked internal deliverables, including the value of stocks traded and trading cycles with economic growth. Kamamia (2018) undertook an analysis of the contributions of macroeconomic variables to the revenue growth of investment banks in Kenya. Finding implies that the inflation rate is positively associated with significant impact, while interest levels have a substantial adverse influence on financial growth. The researcher contrasted, however, with (Kiganda, 2014), who observed that these variables have a negligible effect on bank profitability. On the other hand, the researcher doubts the findings by acknowledging that the regression model applied has many shortcomings, therefore recommending using a superior model in a different study.

From the empirical review, it is now evident that information is scarce with mixed reactions conflicting findings, and glaring inconsistencies, probably due to approaches and investigations methods. As a result, the current studies are inadequate to aid investment banks in overcoming their challenges in Kenya due to mixed findings, resulting in rising uncertainty on equity investments' performance, leading to massive losses among investment banks. On the other hand, these studies majorly favored commercial banks and not investment banks, which operate under different regulations. Hence, these studies cannot be considered to be representative. This study, therefore, sought to model the relationship between inflation, GDP, interest rates, exchange rates (market fluctuations), and financial performance of investment banks to strengthen market sentiment (speculative investment), guide investors and investment banks accordingly. 


\subsection{Objectives of the Study}

The study's general aim was to evaluate the relationship between selected macroeconomic variables and financial performance of investment banks in Kenya. The Specific objective of the study were;

1) To evaluate the relationship between inflation and the financial performance of investment banks in Kenya.

2) To assess the relationship between interest rates and the financial performance of investment banks in Kenya.

3) To investigate the relationship between foreign exchange rate and financial performance of investment banks in Kenya.

4) To determine the relationship between gross domestic products and financial performance of investment banks in Kenya.

\section{Theoretical Review}

The three main theories that are relevant to the current study. These theories are the classical theory of Inflation, modern portfolio theory, classical economic theory (flow-oriented Models).

\subsection{Arbitrage Pricing Theory (APT)}

APT is an asset pricing model that assumes that returns of an asset can be predicted with the linear relationship of returns of expected assets alongside macroeconomic variables that impact the asset's risk. APT was developed by (Stephen, 1976), an American economist, as an alternative to the capital pricing model. Whereas the capital market pricing model supposes markets are perfectly efficient in pricing securities, APT sometimes presupposes markets overprices securities before the market finally corrects to fair value. APT provides investors and analysts a multi-factor pricing method for securities on the basis of the relationship between risks involved and the expected return of financial assets (Paavola, 2006).

The objective of ATP is to pinpoint securities' fair market price that may not be priced correctly. This theory presupposes that market action is not always perfectly efficient and sometimes leads to mispricing of assetseither undervalued or overvalued- for a short period. Nevertheless, to an arbitrageur, this brief mispricing of securities may come as an opportunity to make profits with fewer risks.

APT is considered more complex and flexible than the capital pricing model. APT allows analysts and investors to customize their market insights. However, it might be more difficult to use because it requires a lot of time to evaluate all the factors that may affect asset prices. There are several assumptions in the arbitrage pricing theory. First, this theory works with a pricing model that considers multiple sources of risk. Whereas the capital market pricing model looks at only one factor of the risk level of the general market, the APT model considers several macroeconomic factors that influence the risk and returns. Second, the macro-economic factors carry a systematic risk that can be lowered through diversification. Third, investors have to choose their own risk and returns profile based on the sensitivity and premiums of the macroeconomic risk factors. High risk takers will exploit the variations in real and expected earnings on the asset using arbitrage.

APT is highly relevant in this study. APT concerns with identifying macroeconomic variables which influence stock returns. In this study, APT influences the financial performance of equity investments among investment banks. Macroeconomic forces affect dividend payouts providing evidence to the belief that an equilibrium exists between macroeconomic variables and equity investment performance (Tursoy, Gunsel, \& Rjoub, 2008). APT helped discover the relationship between macroeconomic variables and the financial performance of equity investments among investment banks in Kenya.

\subsection{Modern Portfolio Theory (MPT)}

Harry Markowitz (1952) pioneered a philosophy popularly known as the modern portfolio theory (MPT). MPT explains how risk-averse investors should create investment approaches to maximize or enhance investment returns depending on a given degree of market uncertainty, noting that higher yields are correlated with higher risks. According to (Markowitz, 1952), it is possible to build an investment portfolio to offer the highest potential returns for a given amount of risk.

This theory argues that investment return characteristics and risk should not be the only determinants. Still, one should evaluate them based on how the investment impacts the overall portfolio's return and risk. MPT strongly suggests an investor should construct a collection of numerous assets to maximize gains at a specific degree of risk. Equally, given the optimal amount of projected investment returns, an investor could create a portfolio with the lowest potential risk. Based on statistical parameters like correlation and variance, a return on investment is less significant than the performance of portfolio investment (Chen, 2020). MPT assumes investors are generally 
risk-averse, which implies investors favor a rather diversified investment for a given level of returns.

Further, the theory assumes that if investors expect high yields, they are more willing to take up higher risk portfolios. A portfolio's risk is a complicated function of correlations of each pair of assets and variances of each asset (Chen, 2020). This theory also assumes that investors are well balanced and markets highly organized. This theory is highly relevant in asset investment and Performance within investment banks. Expected returns and associated risks are key issues that determine the actions of these banks concerning asset investments. This theory offers a context that makes the whole investment process possible. Through this theory, it has been possible to inspire inactive investment techniques and shape the management of institutional portfolios.

The MPT is found highly relevant to the current study. The present research is shaped by the uncertainty of both individual and institutional investors in equity investments. Investors diversify their portfolio by investing in more than one equity investment to reap the maximum benefits of diversification, the benefit being risk minimization. This theory quantifies the benefits of diversification and the correct combination of stocks in one's basket. This theory champions the expected returns and associated risks as critical factors considered in investment. Investors' uncertainties are associated with impending investment risks. The risk for individual stock returns has two parts: systematic risk and unsystematic risk (Mcclure, 2020). This study sought to look at the systematic risk that accompanies macroeconomic variables such as interest rates. These are risks that are beyond the investor's control. However, investors need to understand them and factor them in their investment models.

\subsection{Classical Economic Theory}

The very earliest concept of this theory is that of 'flow-oriented' models (Dornbusch \& Fisher, 1980). This theory opines that equity markets and currency fluctuations can relate, implying that a shift in currency exchange shapes market competitiveness, returns of firms, ultimately manipulating broader economic variables. In other words, currency fluctuations would trigger the equity market (prices). This concept is founded on the general perspective of the Efficient Market Theory (EFM). That share values represent the estimated current value of the forecasted future cash flows of a firm, implying that any trend that influences the cash flow of business would be expressed in the share price of that firm, as EFM suggests. According to (Frank \& Young, 1972), one of the early divergences in manipulating equity prices by exchange rates was whether the organization was of a global corporate or national nature. If the company is beyond the borders, the fluctuations in currency rate could impact the value of the overseas operations, reflecting in the financial statement as either gain or loss, influencing the share price either downwards or upward. As evidenced in the empirical review, most organizations are affected by variations in exchange rates. Implying organizations should take precautions to reduce the impact of these fluctuations on their performance.

This theory informed the study since exchange rates results to lower economic activities, reducing the earnings due to low investment returns of investment banks. On the other hand, a sudden rise in exchange rates heightens uncertainty about the economy leading to lower earnings forecasts for investment banks, affecting their performances.

\section{Conceptual Framework}

A conceptual framework is a diagrammatic representation of the relationship among study variables. The relationship between macroeconomic variables and financial performance of equity investments has been explained both empirically and theoretically by several studies reviewed in the literature.

\section{Dependent variables}

Inflation

Measured using change in CPI quarterly (July 2006- Dec 2019)

Interest Rates

As measured by CBK lending rates quarterly (July 2006- Dec 2019)

Foreign Exchange

Change in exchange US dollars/Ksh quarterly (July 2006- Dec 2019)

GDP

Real GDP growth rate quarterly (July 2006- Dec 2019)

Independent variable

Financial Performance

Return on Assets (ROA)

(July 2006 - 2019)

Figure 1. Conceptual framework 


\section{Research Methodology}

A causal research design was employed to measure the effect an absolute change had on existing assumptions and norms. In the current study, the researcher intended to establish the link between the selected macroeconomic variables and the performance of Kenya's investment banks. The study targeted all the investment banks authorized by CMA, and have been active from $1^{\text {st }}$ July 2006 to December 2019 . The researcher collected data from $1^{\text {st }}$ July 2006 since CBR was introduced in June 2006. Again, a fairly large period (over ten years) was needed due to constant fluctuations of macroeconomic variables in Kenya. As of April 2020, there were 16 investment banks licensed and regulated by the Capital Markets Authority (CMA, 2020).

The population census was employed to collect data on all 16 investment banks. According to Creswell (2002), data collection is a means by which data is acquired from a study's chosen subjects. For this research, secondary data was collected using the data collection Sheet. During this study, data collected was analyzed using excel and Stata version 12. The study also adopted an econometric model to investigate the effects of selected macroeconomic variables on the performance of investment banks. Either Vector autoregressive (VAR) model or Vector Error Correction (VEC) Model were accustomed to analyzing the long-run and short-run relationship between macroeconomic variables and the performance of investment banks in Kenya.

\section{Results and Findings}

The study's main objective was to evaluate the relationship between selected macroeconomic variables and the financial performance of investment banks in Kenya. Secondary data was collected from all investment banks (16) authorized by CMA, and have been active from January 2006 to December 2019. The data were analyzed using STATA. VAR model and VEC model was used. Granger causality test model measured the linear causation between macroeconomic variables and the performance of investment banks in Kenya.

\subsection{Trend Analysis}

Trend analysis refers to a statistical method and procedure used in showing the movement of an observed data over a specified period. This section presents the trend analysis for the independent variable (inflation, gross domestic product, interest rates, and foreign exchange rate) and the dependent variables (financial performance of equity investments).

\subsubsection{Inflation (InfR)}

The study sought to determine the inflation in Kenya between July of 2006 to December of 2019, and the findings were as presented in Figure 1. and Figure 2

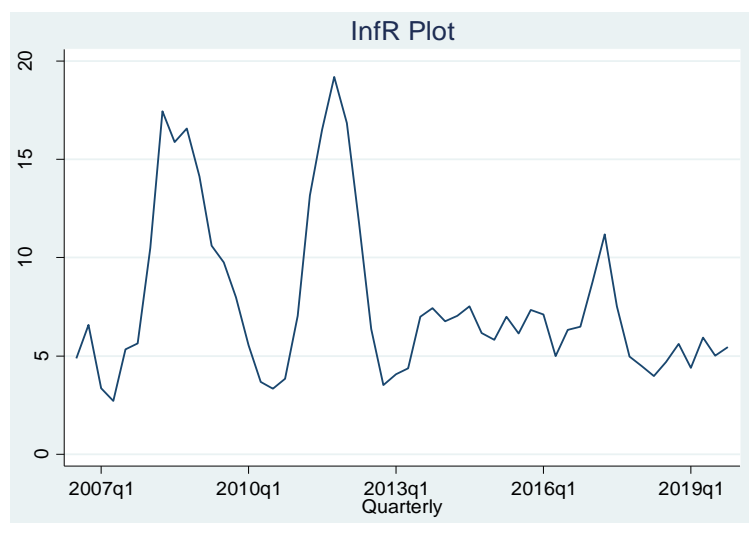

Figure 1. InfR Plot

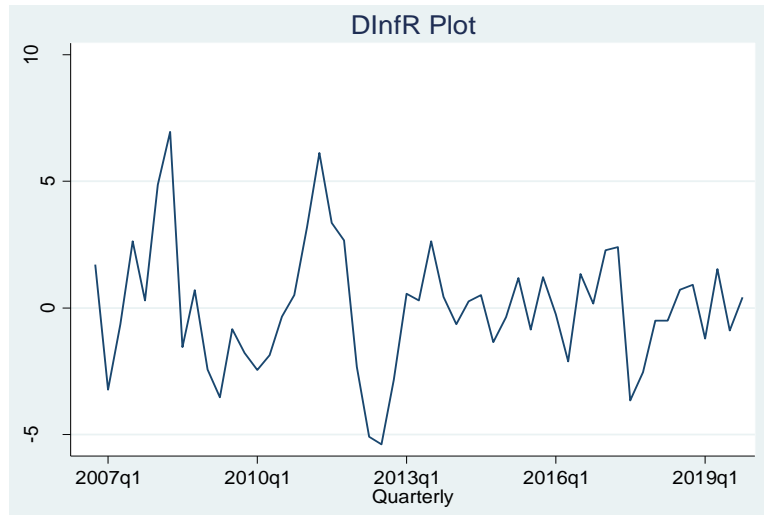

Figure 2. DInfR Plot

Based on the findings presented in Figure 1, it can be seen that the inflation rate in the country fluctuated between July 2006 and December 2019, where a trend is evidenced, suggesting a possibility of nonstationarity. On the other hand, Figure 2 shows no clear trend suggesting stationarity after the first difference. The study, therefore, used the information to analyze the relationships and determine whether the change in the inflation rate had any significant influence on the financial performance of investment banks in Kenya.

\subsubsection{Trend in Interest Rate (InfR)}

The study sought to determine the trend in interest rates in Kenya between July of 2006 to December of 2019, and the findings were as presented in Figure 3 and 4. 


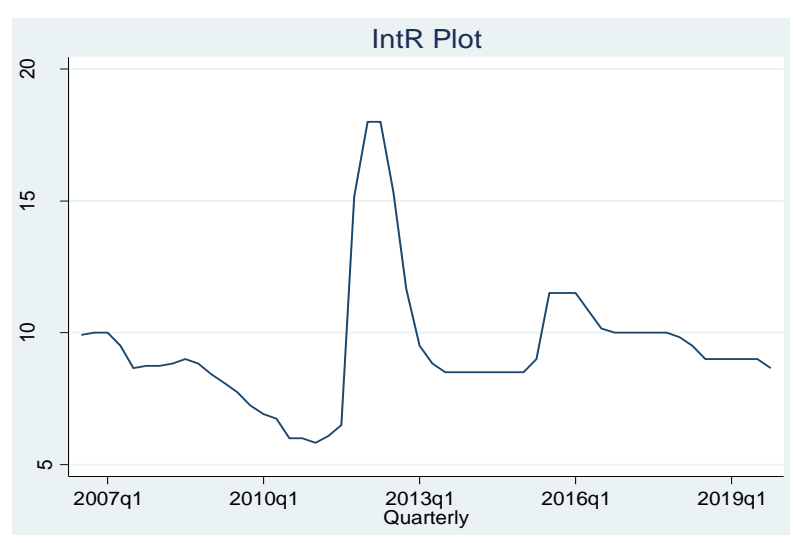

Figure 3. IntR Plot

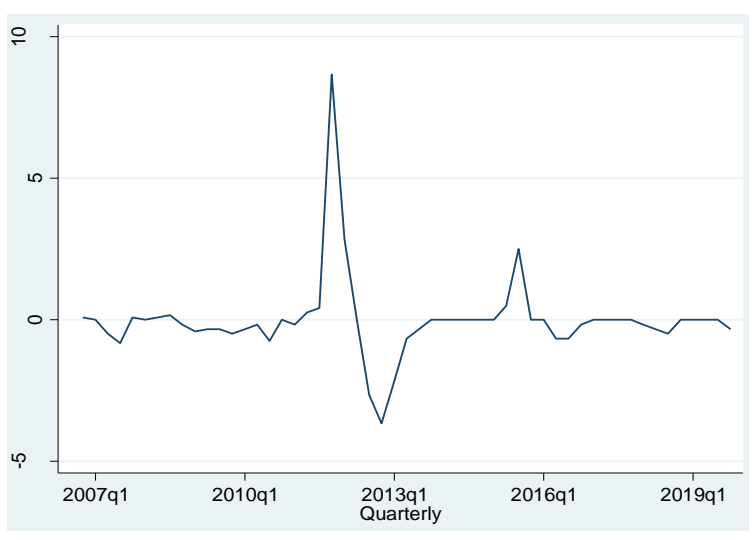

Figure 4. DIntR Plot

The findings presented in Figure 3 shows that there was no clear trend in interest rates recorded in the country, suggesting stationarity similar to Figure 4 after differencing. Each quarter had different rates of interest. It was not clear to determine whether the next quarter, the interest rate would be high or low. Therefore, this study used the information to analyze the relationships and determine whether the fluctuating interest rate affected the financial performance of investment banks in Kenya.

\subsubsection{Trend in Foreign Exchange Rate (ExR)}

The study sought to determine the trend in the foreign exchange rate in Kenya between July of 2006 to December of 2019, and the findings were as presented in Figures 5 and 6.

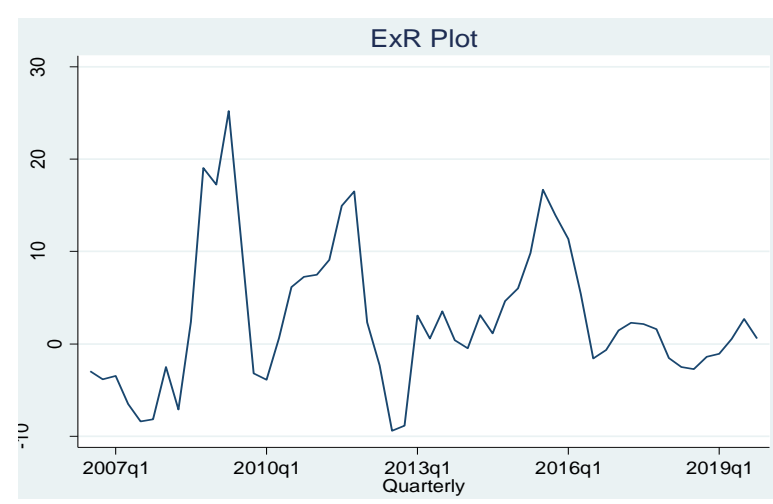

Figure 5. ExR Plot

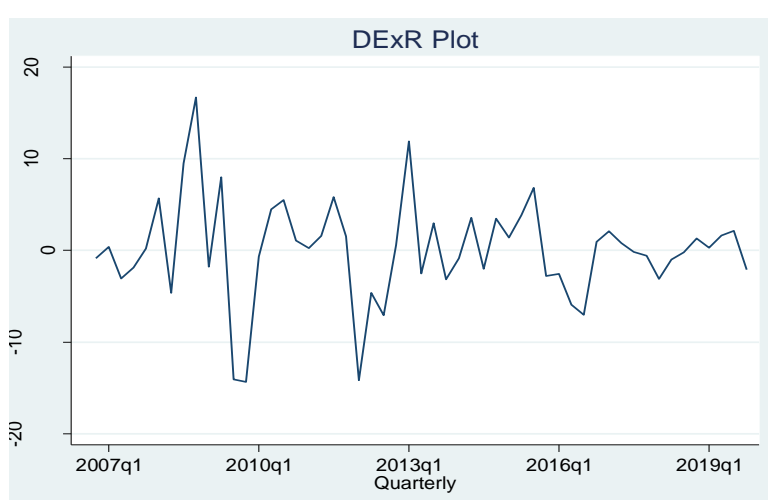

Figure 6. DExR Plot

From the findings in Figure 5, it can be seen that the quarterly foreign exchange rate between July 2016 and December 2019 has been fluctuating with some trend though not very clear over the years, therefore, suggesting the possibility of nonstationarity. On the other hand, Figure 6 shows no trend suggesting stationarity after the first difference. The study consequently adopted the outcomes to analyze the relationship between foreign exchange and the financial performance of investment banks in Kenya.

\subsubsection{Trend Gross Domestic Product}

The study sought to determine the trend in the gross domestic product in Kenya between July of 2006 to December of 2019, and the findings were as presented in Figure 7 and 8. 


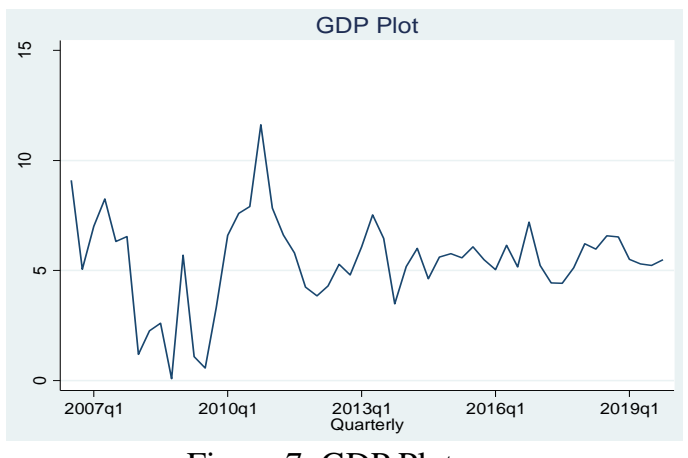

Figure 7. GDP Plot

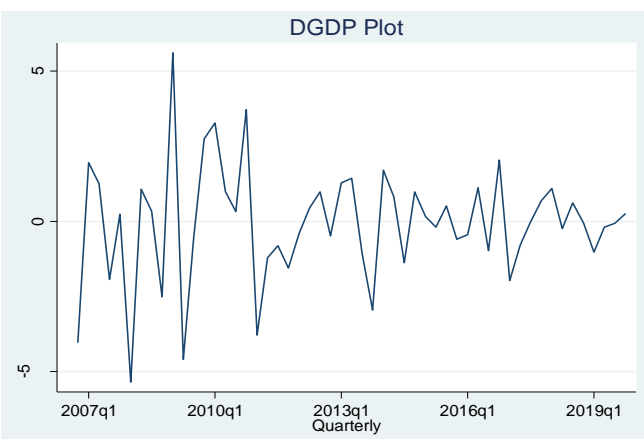

Figure 8. DGDP Plot

The findings in Figure 7 show that the GDP of the country had a clear trend. Over the period under consideration, the rate of real gross domestic product was fluctuating. The growth in real GDP of the country was used to analyze the relationship and determine its effects on the financial performance of investment banks in Kenya.

\subsubsection{Trend in Return on Asset}

The study sought to determine the trend in the financial performance of equity investments among investment banks in Kenya between July of 2006 and December of 2019. The study used ROA to measure financial performance, and the findings were as presented in Figure 9 and 10.

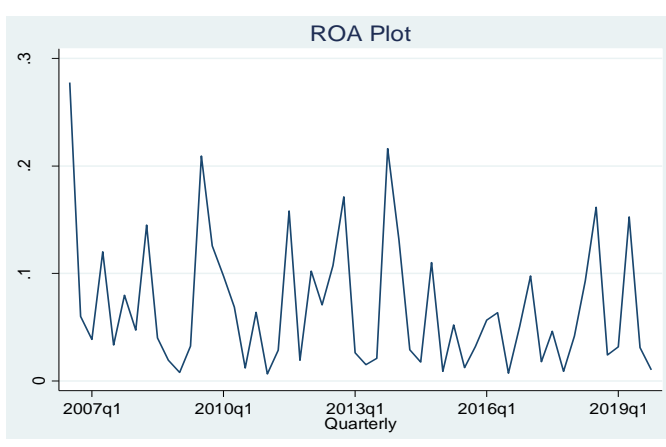

Figure 9. ROA Plot

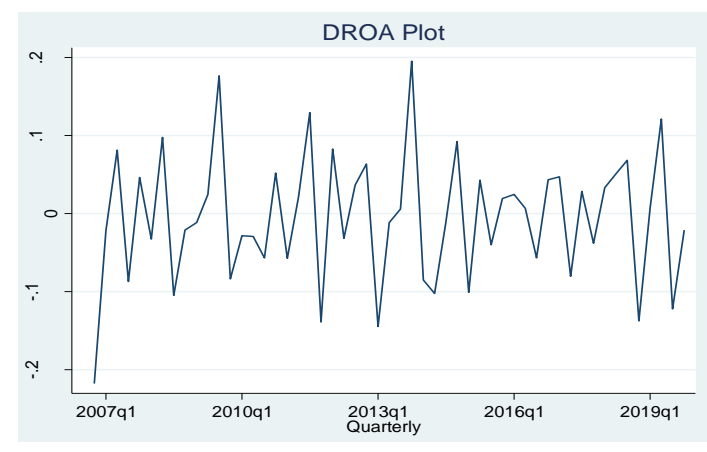

Figure 10. DROA Plot

Figure 9 shows that the financial performance of equity investments among investment banks in Kenya over the period under consideration fluctuated, exhibiting some trend suggesting nonstationarity. Similar to macroeconomic factors presented above, ROA was also seen to fluctuate with no clear trend. Therefore, the study sought to analyze the relationship of those macroeconomic factors and whether they were the reason for fluctuating performance. This was achieved by computing the Granger causality test model.

\subsection{Vector Error Correction Model}

Since this study found that the series are co-integrated, it did not use the VAR, but rater computed the VEC to capture the relationship.

Table 1. Error correction model

\begin{tabular}{|c|c|c|c|c|c|c|}
\hline \multicolumn{4}{|l|}{ Cointegrating equations } & & & \\
\hline Equation & Parms & Chi2 & $\mathrm{P}>$ chi2 & & & \\
\hline _ce1 & 4 & 51.03145 & 0.0000 & & & \\
\hline \multicolumn{7}{|c|}{ Identification: beta is exactly identified } \\
\hline \multicolumn{7}{|c|}{ Johansen normalization restriction imposed } \\
\hline \multicolumn{7}{|c|}{ [95\% Conf. Interval] } \\
\hline ROA & 1 & . & . & . & . & . \\
\hline InfR & -.0013762 & .0088585 & -0.16 & 0.877 & -.0187385 & .0159861 \\
\hline IntR & .0387377 & .0107316 & 3.61 & 0.000 & .0177043 & .0597712 \\
\hline ExR & -.0102441 & .0038016 & -2.69 & 0.007 & -.0176951 & -.0027931 \\
\hline GDP & -.0677602 & .0165177 & -4.10 & 0.000 & -.1001343 & -.0353861 \\
\hline _cons & -.0185841 & . & . & . & . & . \\
\hline
\end{tabular}


The VEC model, the long-run model, commonly referred to as the Johansen normalization restriction, was developed. The restriction was placed on the dependent variable, i.e., error correction term. When interpreting its findings, the signs of the coefficients are reversed. The coefficients were considered significant at a $5 \%$ level of significance.

From the findings, the following counteracting/correction equation was developed;

$$
E C T_{t-1}=0.0186+0.0014 \Delta \operatorname{InflR}_{t-1}-0.0387 \Delta \operatorname{Int} R_{t-1}+0.0102 \Delta E x R_{t-1}+0.0678 \Delta \ln G D P_{t-1}
$$

The findings, therefore, show that in the long-run, inflation has a positive effect on ROA, as indicated by a coefficient value of 0.0014 . The influence was insignificant since the p-value was 0.877 , which greater than the selected significance of (0.05). The findings also show that interest rate negatively influences error correction estimate as indicated by the coefficient value of 0.0387 . The influence was considered significant since the p-value was 0.000 , which is less than the selected $5 \%$ level of significance. The exchange rate has a positive and significant influence on the error estimate, as indicated by the coefficient value of 0.0102 . The p-value was 0.007 , suggesting that influence was significant in the long run p-value is less than the selected level of significance (0.05). Finally, the findings show that GDP has a positive and insignificant influence, as indicated by the coefficient value of 0.0678 and a p-value of 0.000 . Since the p-value is less ta 0.05 , the influence was considered to be negligible in the long run.

These findings, therefore, suggest that inflation, interest rate, exchange rate, and GDP have asymmetric effects on error estimates in the long run.

Table 2. Short-run coefficient

\begin{tabular}{ccccccc}
\hline \multicolumn{1}{c}{ Coef. } & Std. Err. & $\mathrm{z}$ & $\mathrm{P}\rangle|\mathrm{z}|$ & [95\% Conf. Interval] \\
\hline D_ROA & & & & & & \\
_ce1 & & & & & & \\
L1. & -.0182596 & .0756849 & -0.24 & 0.809 & -.01665993 & .1300801 \\
ROA & & & & & & \\
LD. & -.7432399 & .1607773 & -4.62 & 0.000 & -1.058358 & -.4281223 \\
L2D. & -.6582301 & .1763598 & -3.73 & 0.000 & -1.003889 & -.3125713 \\
L3D. & -.2174479 & .1440455 & -1.51 & 0.131 & -.4997719 & .0648761 \\
InfR & & & & & & \\
LD. & -.0023995 & .0055805 & -0.43 & 0.667 & -.0133371 & .0085381 \\
L2D. & -.0019129 & .0055216 & -0.35 & 0.729 & -.0127351 & .0089093 \\
L3D. & -.0025572 & .0063284 & -0.40 & 0.686 & -.0149607 & .0098462 \\
IntR & & & & & & \\
LD. & .0092086 & .0079747 & 1.15 & 0.248 & -.0064215 & .0248386 \\
L2D. & -.0086706 & .0090583 & -0.96 & 0.338 & -.0264245 & .0090834 \\
L3D. & .0050734 & .0077988 & 0.65 & 0.515 & -.010212 & .0203588 \\
ExR & & & & & & \\
LD. & -.002527 & .0022842 & -1.11 & 0.269 & -.007004 & .00195 \\
L2D. & -.0026371 & .0020793 & -1.27 & 0.205 & -.0067124 & .0014383 \\
L3D. & .0044917 & .0019598 & 2.29 & 0.022 & .0006506 & .0083327 \\
GDP & & & & & & \\
LD. & -.0186763 & .0087052 & -2.15 & 0.032 & -.0357383 & -.0016144 \\
L2D. & -.003149 & .0100767 & -0.31 & 0.755 & -.0228991 & .016601 \\
L3D. & .0062371 & .0074866 & 0.83 & 0.405 & -.0084362 & .0209105 \\
_cons & -.0016706 & .0084792 & -0.20 & 0.844 & -.0182895 & .0149483 \\
\hline & & & & & & \\
\hline & & & & & & \\
\end{tabular}

From the findings, the study also developed the generalized VEC model;

$$
R O A_{t}=-0.0017-0.7432 R_{0 A} A_{t-1}-0.0024 \operatorname{InflR}_{t-1}+0.0092 \operatorname{Int}_{t-1}-0.0025 E x R_{t-1}-0.0187 \operatorname{lnGDP_{t-1}}-0.0183 E C T_{t-1}
$$

These findings show that inflation has a negative and insignificant influence on ROA in the short run. This is demonstrated by a p-value of 0.667 , which is greater than the selected level of significance $(0.05)$. Therefore, inflation can be said to have an insignificant negative influence on the financial performance of equity investments among investment banks in Kenya in the short run. The study findings agree with (Doepke et al., 2010) that the Inflation in the country deteriorates customers' purchasing, thereby reducing the demand for goods; this meant that high inflation rates impact negatively on the Performance of companies. It also agrees with (Silva, 2016), whose results showed that Inflation is negatively related to stock prices; however, proportion change 
reviewed that inflation rate positively associated with stocks return.

On the influence of the ROA's interest rate, the findings show that the influence was positive and insignificant, as shown by p-value (0.248) greater than the selected level of significance. The influence was also found to be positive, as demonstrated by the coefficient value of $\mathbf{0 . 0 0 9 2}$. This suggests that interest rate has a positive and insignificant impact on the financial performance of equity investments in the short run. These findings concur with those of (Banton, 2020) that interest rates affect companies' cost and accessibility to credit facilities. A lower interest rate implies the company can access a credit facility at a lower price. With the declining value of obtaining credit, the profitability of firms increases. However, when interest rates are so high, the cost of securing credit increases, which in turn increases production costs. The increased production cost leads to higher product prices, which results in lower demand and company earnings.

The findings also showed that the influence of the exchange rate on ROA was negative, as indicated by the coefficient value of 0.0025 . The findings also showed that the influence was insignificant, as shown by p-value (0.002), which is less than the selected level of significance (0.05). Therefore, the exchange rate has a significant negative influence on the financial performance of equity investments in the short-run at lag 3 . This agrees with (Doepke et al., 2010) that flexible exchange rates are strongly influenced by Forex or currency markets, most of which fluctuate due to the prevailing market dynamics. It also concurs with (Nilsson, 2013) that the results reviewed a very weak association which statistically negligible in the two advanced economies and that association across different points differed widely in the various economic sectors.

On the influence of GDP on ROA, the findings showed that the influence was significant, as indicated by a p-value (0.032) less than the selected level of significance (0.05). The findings further showed that the influence was negative, as shown by the coefficient value of $\mathbf{0 . 0 1 8 7}$, implying that GDP has a negative and significant influence on the financial performance of equity investments among investment banks in Kenya. The study findings concur with (Kimani \& Mutuku, 2013), which revealed a statistically significant but positive relationship between the 20-share index and interest rate, Inflation, and exchange rate. However, the GDP had a meaningful positive relationship. It also agreed with (Babu, 2017), which reviewed a significant positive relationship between Inflation and equity market returns, a positive long-run relationship between real GDP and equity market returns.

The adjustment parameters in _ce1 L1 shows the error correction term. From the findings, the adjusted parameters of GDP are (1.593881) is statistically insignificant at a 5\% level of significance since the p-value was 0.482. This suggests that the previous year's errors, i.e., deviations from long-run equilibrium, are corrected for within the current year at a convergence speed of $159 \%$. ROA responds at an adjustment speed of $1.8 \%$, InfR responds at -8.93 , IntR respond at (-4.63) ExR responds at -8.50

Table 3. Adjustment Parameters

\begin{tabular}{llcccccc}
\hline & & Coef. & Std. Err. & $\mathrm{z}$ & $\mathrm{P}>\mid \mathrm{z}$ & {$[95 \%$ Conf. } & Interval] \\
\hline D_ROA & _ce1 L1. & -.0182596 & .0756849 & -0.24 & 0.809 & -.1665993 & .1300801 \\
D_InfR & _ce1 L1. & -8.929365 & 2.198837 & -4.06 & 0.000 & -7.432757 & -1.8352724 \\
D_IntR & _ce1 L1. & -4.634015 & 1.427956 & -3.25 & 0.001 & -12.28449 & 9.383145 \\
D_ExR & _ce1L1. & 8.504763 & 5.704334 & 1.49 & 0.136 & -2.675526 & 19.68505 \\
D_GDP & _ce1L1 & 1.593881 & 2.264996 & 0.70 & 0.482 & -2.845429 & 6.033191 \\
\hline
\end{tabular}

\subsubsection{Forecast Error Variance Decompositions}

The above test was applied in the Vector Autoregressive model to ease and facilitate understanding of the model and how the exogenous shocks explain forecast error variance in the variables under consideration.

Table 4. Fevd

\begin{tabular}{|c|c|c|c|c|c|}
\hline \multicolumn{6}{|c|}{ Results from var1 } \\
\hline step & (1) & (2) & (3) & (4) & (5) \\
\hline & fevd & fevd & fevd & fevd & fevd \\
\hline 0 & 0 & 0 & 0 & 0 & 0 \\
\hline 1 & 1 & .004083 & .007189 & .014672 & .021129 \\
\hline 2 & .876315 & .047354 & .054398 & .019621 & .033865 \\
\hline 3 & .807529 & .085385 & .055754 & .048244 & .05915 \\
\hline 4 & .711786 & .086266 & .06022 & .046687 & .058889 \\
\hline 5 & .713231 & .071151 & .071134 & .044894 & .06932 \\
\hline
\end{tabular}


In the short run, i.e., quarter 3, a shock to ROA (fevd 1) account for 80 percent of the variation of fluctuation in ROA (own shock), 8.5 percent of the variation in $\operatorname{dInfR}$ (fevd 2), 5.56 percent of variation in $\mathrm{dIntR}$ (fevd 3), 4.82 percent variation in dExR (fevd 4) and finally 5.9 percentage variation in DGDP (fevd 5).

On the other hand, a shock to dInfR (fevd 2) account for 2.26 percent of the variation of fluctuations in dROA, while a shock to dIntR (fevd 3) account for 2.4 percent of the variation of fluctuations in dROA, a shock to dExR (fevd 4) account for 2.08 percent of variations of fluctuations in dROA, and shock to dGDP (fevd 5) account for 11.12 percent of the variation in fluctuations in $\mathrm{dROA}$ as shown below.

Table 5. Fevd

\begin{tabular}{lccccc}
\hline step & $\begin{array}{c}(1) \\
\text { fevd }\end{array}$ & $\begin{array}{c}(2) \\
\text { fevd }\end{array}$ & $\begin{array}{c}(3) \\
\text { fevd }\end{array}$ & $\begin{array}{c}(4) \\
\text { fevd }\end{array}$ & $\begin{array}{c}(5) \\
\text { fevd }\end{array}$ \\
\hline 0 & 0 & 0 & 0 & 0 & 0 \\
1 & 1 & 0 & 0 & 0 & 0 \\
2 & .876315 & .014631 & .023537 & .021495 & .064023 \\
3 & .807529 & .025267 & .023947 & .02083 & .122426 \\
4 & .711786 & .022855 & .023634 & .130482 & .111243 \\
5 & .713231 & .022752 & .025685 & .124524 & .113808 \\
\hline
\end{tabular}

\section{Conclusions}

The general objective of this research was to analyze the relationship between the selected macroeconomic variables and the financial performance of investment banks in Kenya. The study analyzed the relationship using four macroeconomic variables comprising of inflation rate, interest rates, foreign exchange rate and real GDP while financial performance of investments banks was measured using return on assets. The study established that inflation rate has positive relationship even though insignificant in explaining financial performance of investment banks, foreign exchange rate and real GDP have significant and positive relationship with financial performance, while interest rates had significant and negative relationship in the longrun.

This study therefore concludes that by analyzing the past values of interest rates, foreign exchange rates and real GDP is possible to forecast present and future financial performance of investment banks all other factors held constant. On the hand, the past values of inflation rate are negligible in forecasting current and future financial performance of investment banks.

The outcomes of this study are consistent with the conclusions of arbitrage pricing model that return on asset can be forecasted with the linear relationship of returns of expected assets alongside macroeconomic variables that impact the asset's risk. Also, the findings are in agreement with modern portfolio theorist who explains that risk-averse investors should create investment approaches to maximize or enhance investment returns depending on a given degree of market uncertainty, noting that higher yields are correlated with higher risks. This theory quantifies the benefits of diversification and the correct combination of stocks in one's basket. Additionally, the study outcomes are also consistent with the flow oriented models (Dornbusch \& Fisher, 1980) which opines that equity markets and currency fluctuations can relate, implying that a shift in currency exchange shapes market competitiveness, returns of firms, ultimately manipulating broader economic variables.

\section{Recommendations}

Considering the significant and negative relationship between interest rates and financial performance, significant and positive relationship between foreign exchange rate, real GDP and financial performance of investment banks, the study therefore recommends investor, including financial investors, to methodically analyze and monitor fluctuations in macroeconomic variables and understand how they affects their financial performance. The study also recommends investors to use the formulated model to predict the current and future financial performance hence leading to sound investment decisions.

The study also recommends regulators to put up policies to guarantee stability of these macroeconomic variables. Firmness in these macroeconomic variable would lower uncertainty in the market resulting to stability in financial performance.

This study additionally recommends investments banks to embrace diversification to caution themselves against these risk arising as a result of fluctuation in macroeconomic variables therefore lowering their losses in the event that there is significant variation in macroeconomic variables. 


\section{Areas for Further Studies}

The study found that there was a fluctuation in macroeconomic variables over the past ten years. This study, therefore, suggest further research on the factors contributing to macroeconomic factors changes in Kenya. Further, the study also recommends further research on the relationship between macroeconomic variables and the performance of equity among Kenya's investment banks. Lastly, Different reviews should also be replicated in other institutions such as brokerage firms.

\section{References}

Alper, D., \& Anbar, A. (2011). Bank Specific and Macroeconomic Determinants of Commercial Bank Profitability: Empirical Evidence from Turkey. Business and Economics Research Journal, 2(2), 139-152. Retrieved from http://www.berjournal.com

Anyanzwa, J. (2019). Kenyan banks weighed down by unprofitable stockbroking firms. Retrieved from https://www.theeastafrican.co.ke/tea/business/kenyan-banks-weighed-down-by-unprofitable-stockbroking-f irms-1421992

Audited Financial Results - Nairobi Securities Exchange (NSE). (2020). Retrieved from https://www.nse.co.ke/member-firms/company-financial-results/audited-financial-results.html

Babarinde, O. (2012). The private equity market in Africa: trends, opportunities, challenges, and impact. The Journal of Private Equity, 16(1), 56-73. https://doi.org/ 10.3905/jpe.2012.16.1.056

Babu, S. O. (2017). Effect of inflation on stock market returns at Nairobi Security Exchange. University of Nairobi.

Chen, J. (2020). Investment Securities. Retrieved on May 26, 2020 from https://www.investopedia.com/terms/i/investment-securities.asp

Ibrahim, T. M., \& Agbaje, O. M. (2013). The Relationship between Stock Return and Inflation in Nigeria. European Scientific Journal, 146-157.

Jamil, M., \& Ullah, N. (2013). Impact of Foreign Exchange Rates on Stock Prices, Journal of Business and Management, 7(3), 45-51. https://doi.org/10.9790/487X-0734551

Kenya Bankers Association. (2020). Bankers Survey Projects Pandemic-led Business Slowdown, Highlights Commitment to Support Economy. Retrieved on May 26, 2020 from https://www.kba.co.ke/news105.php

Kithome, L. (2017). The Relationship Between Foreign Exchange Rates and Stock Market Returns in Nairobi Securities Exchange. Retrieved from http://erepository.uonbi.ac.ke/handle/11295/103174

Kwon, A., \& Shin, H. (1999). Determinants of Commercial Bank Interest Margins and Profitability: Some International Evidence. World Bank Economic Review, 13, 379-408. https://doi.org/10.1093/wber/13.2.379

Makeri, B. N. (2014, October 1). The relationship between exchange rate fluctuations and stock prices in Rwanda stock exchange. Retrieved from http://erepository.uonbi.ac.ke/handle/11295/75090

Makori, N. G. (2017). The effect of exchange rate changes on stock market returns at the Nairobi Securities Exchange. University of Nairobi.

Markowitz, H. (1952). Portfolio Selection. The Journal of Finance, 7(1), 77. https://doi.org/10.2307/2975974

Mugambi, M., \& Okech, T. C. (2016). Effect of Macroeconomic Variables on Stock Returns of Listed Commercial Banks in Kenya. International Journal of Economics, Commerce and Management, 4(6), 390-418.

Muthui, F. K. (2018). Effect of selected macroeconomic variables on share prices of listed firms on the Nairobi securities exchange. University of Nairobi.

Naik, P. K., \& Padhi, P. (2012). The Impact of Macroeconomic Fundamentals on Stock Prices Revisited: Evidence from Indian Data. Eurasian Journal of Business and Economics, 5(10), 25-44. https://doi.org/10.2139/ssrn.2150208

Nairobi Securities Exchange. (2020). List of investment banks in Kenya. Retrieved on May 14, 2020 from https://www.nse.co.ke/member-firms/firms.html

Ngeno, R. K. (2018). Determinants of Financial Performance of Investment Banks in Kenya. Unpublished Master Thesis submitted to the University of Nairobi.

Ongore, V. O. (2013). Determinants of Financial Performance of Commercial Banks in Kenya. International 
Journal of Economics and Financial Issues, 3(1), 237-252.

Osamwonyi, P. I. S., \& Michael, C. I. (2014). The Impact of Macroeconomic Variables on Profitability of Listed Commercial Banks in Nigeria. European Journal of Accounting Auditing and Finance Research, 2(10), 85-95.

PWC. (April 2015). East Africa Private Equity \& Venture Capital Association (EAVCA) - 2015/2016 Budget Submission. Nairobi, Kenya.

Reddy, D. V. (2012). Impact of inflation and GDP on stock market returns in India. International Journal of Advanced Research in Management and Social Sciences.

Ruibi, K. M. (2012, November 1). Impact of investment banking on economic growth in Kenya. Retrieved from http://erepository.uonbi.ac.ke/handle/11295/12794

Zhang, C., \& Dong, L. (2011). Determinants of Bank Profitability: Evidence from the U.S Banking Sector. Simon Fraser University.

\section{Copyrights}

Copyright for this article is retained by the author(s), with first publication rights granted to the journal.

This is an open-access article distributed under the terms and conditions of the Creative Commons Attribution license (http://creativecommons.org/licenses/by/4.0/). 